\title{
Behaviour of multi-layered geocell reinforced bed subjected to repeated load
}

\author{
Omid Khalaj ${ }^{*}$, Seyed Naser Moghaddas Tafreshi, Bohuslav Mašek, Andrew R. Dawson
}

\begin{abstract}
This paper describes a series of the plate load tests performed in a test pit measuring $2000 \times 2000 \mathrm{~mm}$ in plane and $700 \mathrm{~mm}$ in depth. To simulate traffic loadings, fifteen loading and unloading cycles were applied to the loading plate with amplitudes of 400 and $800 \mathrm{kPa}$. The optimum depth of the top most layer of geocell and the optimum vertical spacing of geocell layers, based on plate settlement, are both approximately 0.2 times loading plate diameter. The results show that installation of the geocell layers in the foundation bed decreases the accumulated plastic and total settlements of loading plate, in addition to increase its elastic settlement. Efficiency of geocell reinforcement was decreased by increasing the number of the geocell layers for all applied stress levels and number of cycles of applied loading. The results of the testing reveal the ability of the multiple layers of geocell reinforcement to 'shakedown' to a fully resilient behavior after a period of plastic settlement except when there is little or no reinforcement and the applied cyclic pressure are large. When shakedown response is observed, then both the accumulated plastic settlement prior to a steady-state response being obtained and the resilient settlements thereafter are reduced. The results depicted that the use of four layers of geocell respectively decreases the total and residual plastic settlements about $53 \%$ and $63 \%$ and increases the resilient settlement of $145 \%$ compared with the unreinforced case.
\end{abstract}

Keywords- Cyclic loading; Multiple geocell layers; Residual and resilient deformations

\section{Introduction}

In the recent decades, geosynthetic materials have been increasingly used in geotechnical engineering applications for different purposes, e.g., stable embankments and construction of footing over soft soil, railway embankments, road construction layers and pavement system (e.g., Madhavi Latha and Rajagopal, 2007; Bathurst et al., 2009; Pokharel et al., 2010; Moghaddas Tafreshi et al., 2013; Boushehrian et al., 2011; Koerner, 2012; Yang et al. 2012; Thakur et al., 2012; Tanyu et al., 2013).

*Omid Khalaj/Post-Doctoral Research Fellow (Coresponding Author) Bohuslav Mašek/Professor

Research Center of Forming Technology / University of West Bohemia Czech Republic

Seyed Naser Moghaddas Tafreshi/Professor

Faculty of Civil Engineering / Khajeh Nasir Toosi University of Technology

Islamic Republic of Iran

Andrew R. Dawson/Associate Professor

Nottingham Transportation Engineering Centre / University of Nottingham United Kingdom

Although planar reinforcements have most often been studied, several investigations have also highlighted the beneficial use of single layer of geocell reinforcement in the construction of foundations and embankments over soft soil (Madhavi Latha et al., 2007; Sireesh et al., 2009; Pokharel et al, 2010; Moghaddas Tafreshi et al., 2014; Yang et al., 2012; Chen et al., 2013; Khalaj et al., 2015).

The literature above indicates that there is a lack of studies into the behaviour of foundation bed supported by geocell reinforcing layers with vertical spacing between successive layers. Geosynthetic inclusions would be most effective if used in the zone significantly stressed by the loading surface (e.g., footing or tire wheel) - which may be over a depth of 1 or 2 width/diameters beneath the footing/tire wheel. The heights of commercially produced geocells are usually standard and manufacturers of geocell produce them at heights less than $200 \mathrm{~mm}$ (available cell depths in Europe and the USA) and also using a single thick layer of geocell beneath the tire wheel/footing would likely make compaction of cell-fill extremely difficult (Thakur et al., 2012), consequently decreasing the performance of a thick single layer of geocell. Hence, the use of several layers of geocell (in this paper, two geocell layers) each with a thickness of $100 \mathrm{~mm}$ and with vertical spacing between successive layers of geocell is a practical alternative and could be a beneficial means of reinforcing the soil beneath a loading surface, this is the main subject of this article.

\section{Materials}

\section{A. Backfill Soil}

The backfill soil used in the testing program is a granular soil with grain sizes between 0.01 and $38 \mathrm{~mm}$ with a specific gravity of 2.68 ( $\mathrm{Gs}=2.68)$. It has a Coefficient of uniformity, $\mathrm{C}_{\mathrm{u}}$, of 33.82 , Coefficient of curvature, $\mathrm{C}_{\mathrm{c}}$, of 2.36 , an effective grain size, D10, of $0.17 \mathrm{~mm}$, and mean grain size, D50, of 4.05 which is classified as well graded sand with letter symbol "SW" in the unified soil classification system (ASTM D 2487-11). The maximum and minimum void ratio $\left(\mathrm{e}_{\max }\right.$ and $\left.\mathrm{e}_{\min }\right)$ of the sand were obtained as 0.74 and 0.24 , respectively. According to ASTM D 1557-12, the maximum dry density was about $20.62 \mathrm{kN} / \mathrm{m}^{3}$, which corresponds to an optimum moisture content of $5.7 \%$. The angle of internal friction of soil, through triaxial compression tests at wet density of $19.58 \mathrm{kN} / \mathrm{m}^{3}$ was obtained $40.5^{\circ}$. This soil was used to fill the geocell and to place between the geocell layers.

\section{B. Geocell}

The geocells used were made of a type of a non-woven polymeric geotextile thermo-welded to form a honeycomb structure with an open top and bottom. The type of geotextile is non-woven with weight of $190 \mathrm{~g} / \mathrm{m}^{2}$, effective opening size of $0.08 \mathrm{~mm}$ and thickness of $0.57 \mathrm{~mm}$ under 2 $\mathrm{kN} / \mathrm{m}^{2}$. The geotextile requires an ultimate tensile strength 
of $13.1 \mathrm{kN} / \mathrm{m}$ and load of $5.7 \mathrm{kN} / \mathrm{m}$ to attain $5 \%$ strain (i.e. the stiffness of the geotextile equals $114 \mathrm{kN} / \mathrm{m}$ at $5 \%$ strain). The geocell has the pocket size and height of $110 \times 110 \mathrm{~mm}^{2}$ and $100 \mathrm{~mm}$, respectively. The ratio of the maximum geocell pocket size $(\mathrm{d}=110 \mathrm{~mm})$ to diameter of loading plate $(\mathrm{D}=300 \mathrm{~mm})$ considered $0.37(\mathrm{~d} / \mathrm{D}=0.37)$ in all tests. Fig. 1 shows a view of geocell layer in the test pit.

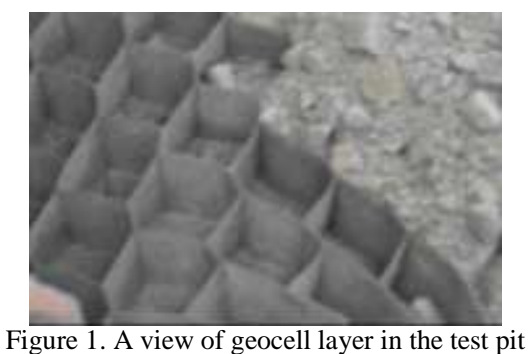

\section{Experimental Program}

To investigate the effect of geocell reinforcement in the deformation of pavements, a full scale model test of a standard plate load was conducted in an outdoor test pit. The test pit, measuring $2000 \mathrm{~mm} \times 2000 \mathrm{~mm}$ in plan, and 700 $\mathrm{mm}$ in depth, was excavated in natural ground to construct the geocell layers. The schematic cross-section of the test set-up of the foundation bed containing geocell layers, the loading plate model, loading system and data measurement system (dial gauges) and the geometry of the test configurations, is shown in Fig. 2. A hand operated hydraulic jack imposed by a manually-operated pump and supported against a strong reaction frame applied loads on a steel rigid circular plate (as a loading surface) of $300 \mathrm{~mm}$ diameter and $25 \mathrm{~mm}$ in thickness located on the center of the trench surface. An additional $10 \mathrm{~mm}$ thick rubber base was attached at the bottom of the loading plate to simulate the rubber tire contact with the ground surface. The hydraulic jack applied loading on the pre-calibrated load cell with a capacity of $4000 \mathrm{~kg}$ and an accuracy of $\pm 0.01 \%$ full scale which was located between the loading shaft and circular plate (soil surface) and connected to a load cell reader.

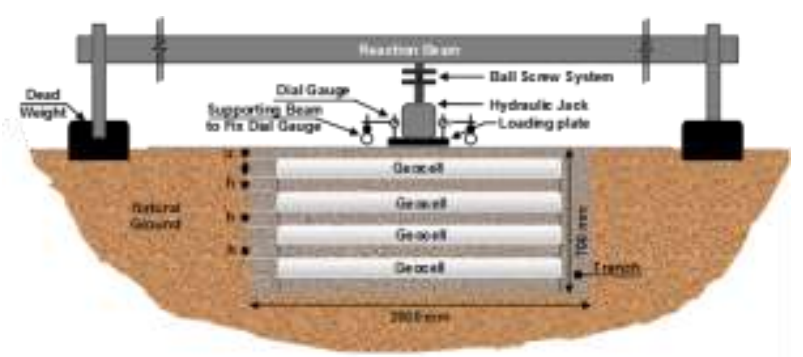

Figure 2. Schematic cross-section of the test set-up (not to scale)

To compact the layers of foundation bed including the unreinforced soil layers and the soil inside the geocell layers, a walk-behind vibrating plate compactor with the depth of influence between 50-100 mm, was used. In all the tests, the compactor passed over the backfill at ten levels being $0,60,160,220,320,380,480,540,640$, and $700 \mathrm{~mm}$ from the level of the base of the loading plate. To achieve the required density of $18.50 \mathrm{kN} / \mathrm{m}^{3}$ for the unreinforced layers (approximately $90 \%$ of maximum soil dry density) and of $18 \mathrm{kN} / \mathrm{m}^{3}$ for the geocell reinforced layers (approximately $87 \%$ of maximum soil dry density), the compactor used with two and three passes, respectively. Theses density values measured in the three cone tests. The loading arrangements were chosen to represent the tires of typical trucks on a pavement regarding to AASHTO T 22190 and ASTM D 1195-09 which recommend application a few load cycles using repetitive static plate load tests of flexible pavement for use in evaluation and design of airport and highway pavements. It was simulated by distributing wheel loads over an equivalent circular area at the appropriate tire pressure. Hence, loading, unloading and reloading were imposed through the plate at a rate of $1.5 \mathrm{kPa}$ per second. The maximum applied pressure of $800 \mathrm{kPa}$ was chosen to replicate that of a heavy vehicle half-axle with "Super-Single" tire, as used on a common heavy trailer (6 axles and a mean pressure $792 \mathrm{kPa}$ ). In Test Series 1 and 3 (see Table 1), the maximum applied pressure of $800 \mathrm{kPa}$ was divided into two stages being 400 and $800 \mathrm{kPa}$ to simulate half and full traffic loadings. For each stage, fifteen loading and unloading cycles were applied. Preliminary repeated load tests (which are not reported in the paper) showed that (regardless of the number of geocell layers), with increase in the number of load cycles, the rate of change of loaded surface settlements reduces, so that their response has become, approximately, stable within fifteen load cycles at the low level of cyclic pressure $(400 \mathrm{kPa})$. The interest was to establish the likelihood of such a response being disturbed by a greater cyclic pressure $(800 \mathrm{kPa})$. Overall, this implies that a large number of cyclic load applications were not essential.

\section{Test Parameters and Testing Program}

Table 1 shows details of the test series done in this study. The tests on geocell reinforced bed were conducted by varying the depth of the first layer of geocell reinforcement beneath the loading surface $(\mathrm{u})$, the vertical spacing of the geocell layers $(\mathrm{h})$, and the number of geocell layers $(\mathrm{N})$.

TABLE I. SCHEME OF THE CYCLIC PLATE LOAD TESTS FOR UNREINFORCED PAVEMENT AND MULTI-LAYERED GEOCELL-REINFORCED PAVEMENT

\begin{tabular}{|c|c|c|c|c|c|c|}
\hline $\begin{array}{c}\text { Test } \\
\text { Series }\end{array}$ & $\begin{array}{c}\text { Type } \\
\text { of } \\
\text { test } \\
\end{array}$ & $\mathbf{N}$ & $\mathbf{u} / \mathbf{D}$ & h/D & $\begin{array}{l}\text { No. of } \\
\text { Tests }\end{array}$ & $\begin{array}{l}\text { Purpose of } \\
\text { the tests }\end{array}$ \\
\hline 1 & 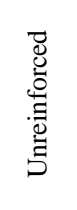 & $\begin{array}{l}--- \\
--- \\
--\end{array}$ & -------- & & $1+2 *$ & $\begin{array}{l}\text { To quantify } \\
\text { the } \\
\text { improvements } \\
\text { due to } \\
\text { reinforcement } \\
\text { s }\end{array}$ \\
\hline 2 & \multirow{3}{*}{ 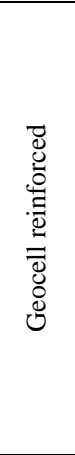 } & 1 & $\begin{array}{c}0,0.1, \\
0.13, \\
0.17,0.2, \\
0.25,0.3, \\
0.6,\end{array}$ & - & $8+4 *$ & \multirow{2}{*}{$\begin{array}{c}\text { To arrive at } \\
\text { the optimum } \\
\text { values of } \mathrm{u} / \mathrm{D} \\
\text { and } \mathrm{h} / \mathrm{D}\end{array}$} \\
\hline 3 & & 2 & 0.2 & $\begin{array}{c}0.15, \\
0.2, \\
0.25, \\
0.4, \\
0.8 \\
\end{array}$ & $5+2 *$ & \\
\hline 4 & & $\begin{array}{l}1, \\
2, \\
3, \\
4\end{array}$ & 0.2 & 0.2 & $4+2 *$ & $\begin{array}{l}\text { To investigate } \\
\text { the effect of } \\
\text { the number of } \\
\text { geocell layers }\end{array}$ \\
\hline
\end{tabular}

*THE TESTS WHICH WERE PERFORMED TWO OR THREE TIMES TO VERIFY THE REPEATABILITY OF THE TEST DATA

The width of the geocell layers (b) and the depth to the top of the first geocell layer below the loading surface $(\mathrm{u})$ 
are expressed in non-dimensional form with respect to loading plate diameter $(\mathrm{D}=300 \mathrm{~mm})$ as, $\mathrm{b} / \mathrm{D}$ and $\mathrm{u} / \mathrm{D}$. In line with the findings of Khalaj et al., (2015), and Thakur et al., (2012), the parameter b/D was held constant in all the tests at $b / D=5$. The variable parameter, $h$, is used to describe the vertical spacing between the bottom of the previous layer of geocell and the top of the next layer. It is expressed in nondimensional form with respect to loading plate diameter (D) as $h / D$, whereas the height of geocell layers $\left(h_{g}\right)$ is expressed in dimensional form equal to $100 \mathrm{~mm}$.

\section{v. Results and Discussions}

\section{A. The optimum value of $u / D$ and $h / D$ ratios}

Variation of plastic (residual) settlement of the loading plate as a function of $\mathrm{u} / \mathrm{D}$ and $\mathrm{h} / \mathrm{D}$ ratios at two amplitudes of cyclic load (400 and $800 \mathrm{kPa}$ ) are shown in Fig. 3. From this figure, it is found that the minimum value of plastic settlement was obtained at $u / D$ and $h / D$ values of approximately 0.2 , irrespective of amplitude of cyclic load.

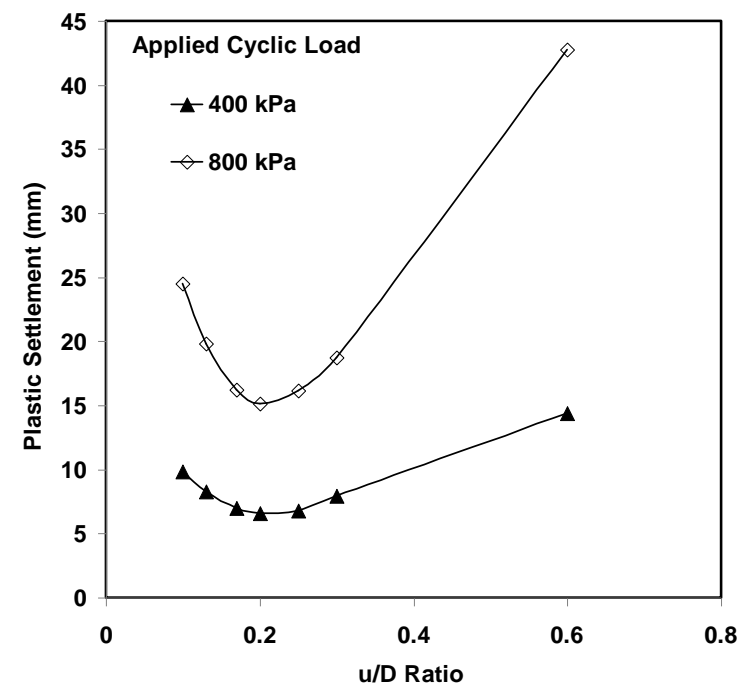

(a)

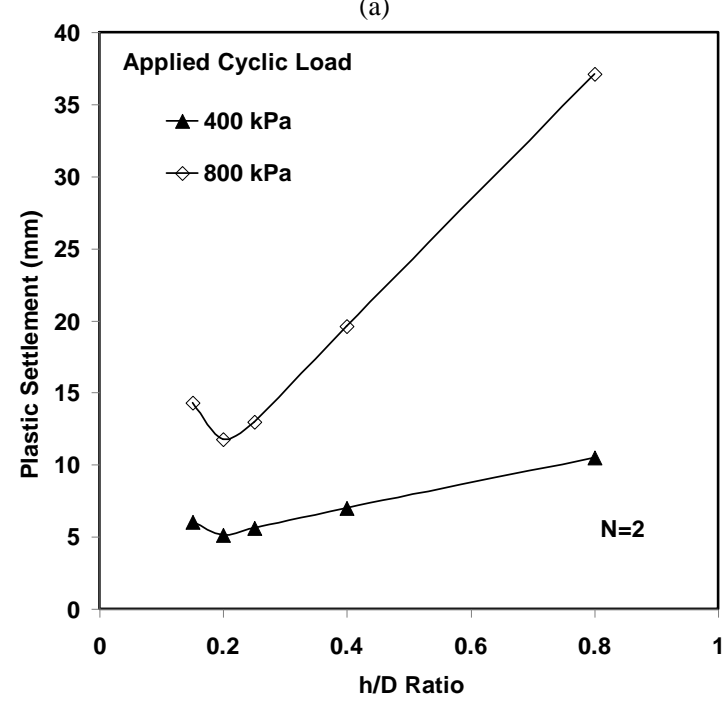

(b)

Figure 3. Variation of plastic settlement With (a) $u / D$ ratio, (b) h/D ratio

Fig. 3a shows the plastic settlement of the geocell reinforced bed initially decreases while the depth of placement increases from $\mathrm{u} / \mathrm{D}=0$ to $\mathrm{u} / \mathrm{D} \approx 0.2$, but that, thereafter, with increase in the $\mathrm{u} / \mathrm{D}$ ratio, it increases again. The slight increase in performance improvement until $\mathrm{u} / \mathrm{D} \approx 0.2$ could be due to the surface soil layer, above the first geocell layer, acting as a cushion, preventing the direct contact of the loading plate base with the cell walls and distributing the applied pressure more uniformly over the cellular geocell. The other probable reason why a small cover thickness is desirable is that the confinement provided by the soil above the geocell layer helps to develop frictional resistance between the geocell and the soil. Likewise, as the value of $\mathrm{u} / \mathrm{D}$ increases beyond 0.2 (toward 0.6 ), the top geocell layer moves out of the zone where it can most successfully interrupt the applied stress field and, hence, the plastic deformation increases. Finally, as expected, with increase in $\mathrm{u} / \mathrm{D}$ ratio to about one, the geocell layer lies almost entirely outside of the significantly stressed zone under the loading plate so that the influence of reinforcement becomes negligible, and the overall response approaches that of an unreinforced pavement foundation. The reduction in plastic settlement at $h / D$ of 0.2 in Fig. $3 b$ may be attributed to the behavior of the soil layer between the first and the second layers of geocell. At small thicknesses it provides effective load spreading without deforming much laterally as it is confined by the geocell reinforcement above and below. However, if the reinforcing layers become too widely spaced, then the material between the geocell layers can be displaced, weakening the overall response. Likewise, Fig. 3b shows an increase in the plastic deformation, regardless of the amplitudes of cyclic load, with increasing $\mathrm{h} / \mathrm{D}$ beyond the optimum value. It would be expected that, when the value of $h / D$ reaches a thickness of 0.8-1 times the loading plate diameter, the second geocell layer would be, largely, outside of the zone of significant stress due to the surface loading, so that its influence on foundation bed behavior would become negligible and the behavior of a reinforced system with two layers of geocell would tend to that of a reinforced system supported by a single layer of geocell. Hence, in the present study, and in order to investigate the effect of multi-layered geocell on the behavior of reinforced system, the $\mathrm{u} / \mathrm{D}$ and $\mathrm{h} / \mathrm{D}$ ratio were subsequently maintained at 0.2 .

\section{B. The effect of the number of geocell layers on the settlement of loading plate}

Fig. 4 shows the variation of loading plate settlement with the applied cyclic pressure. Fifteen first cycles and fifteen second cycles were applied to the loading plate with amplitudes of 400 and $800 \mathrm{kPa}$, respectively. As seen in Fig. 4 , for both the unreinforced and geocell reinforced bases, an initial, rapid total settlement (loading stage) and rapid residual plastic settlement (unloading stage) during the first load applications is followed by secondary settlement at the next load cycles (i.e, second, third, fourth,....., and fifteenth load cycle) that develops at a slower rate. Both the total (peak) and residual plastic settlements caused by the first cycle of applied load form a large portion of the final settlement after all cycles. Overall, in most of the tests performed on the unreinforced and the geocell reinforced foundation, the initial, rapid settlement that took place due to the first cycle of loading gave rise to between $25 \%$ and $70 \%$ of the accumulated residual plastic settlement. This 
ratio decreases from the unreinforced system to the geocell reinforced system. The actual proportion appears to depend on the mass of geocell and on the magnitude of the applied cyclic load. For the unreinforced pavement system, the total and residual settlements tend to increase with the number of load cycles, particularly at higher levels of cyclic loads (i.e., $800 \mathrm{kPa}$ ). For the reinforced bases, regardless of the number of geocell layers, the rate of change of both peak and the residual settlements of the loaded surface reduces as the number of load cycles increases, so that their response has become, approximately, stable after fifteen load cycles (of both 400 and $800 \mathrm{kPa}$ applied load), particularly for the reinforced bases with three and four layers of geocell. Also, it may be clearly observed that, as the number of geocell layers increases (i.e., the increase in the depth of the reinforced zone beneath the loading surface), owing to much stiffer, less peak settlement and less residual plastic settlement cause when compared with the unreinforced case, irrespective of the amplitude of applied cyclic load. For example, at $800 \mathrm{kPa}$ amplitude of applied load and at load cycle number of 15 , the residual settlement values are about 41.03, 33.02, 23.10, 17.43, and $15.39 \mathrm{~mm}$ for unreinforced bed, and geocell reinforced bed with one, two, three and four layers of geocell, respectively.

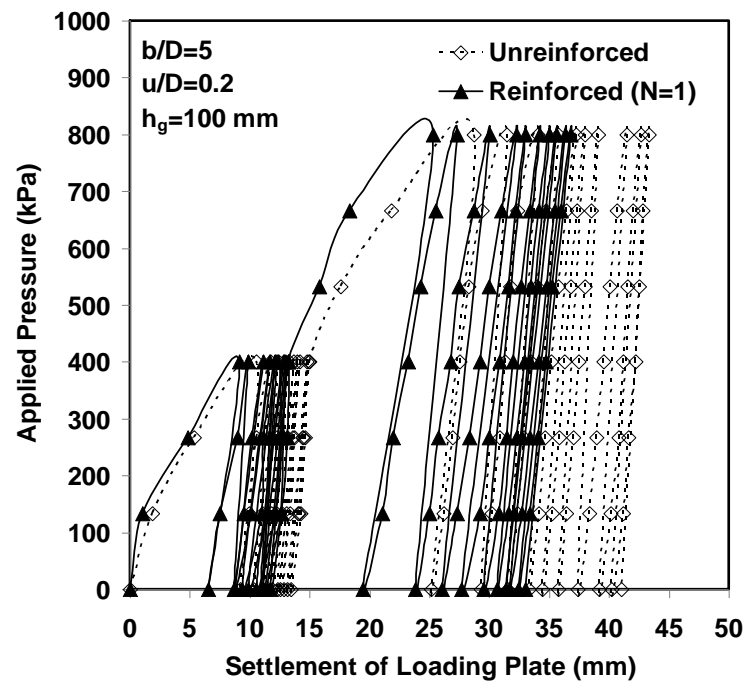

(a) $\mathrm{N}=1$

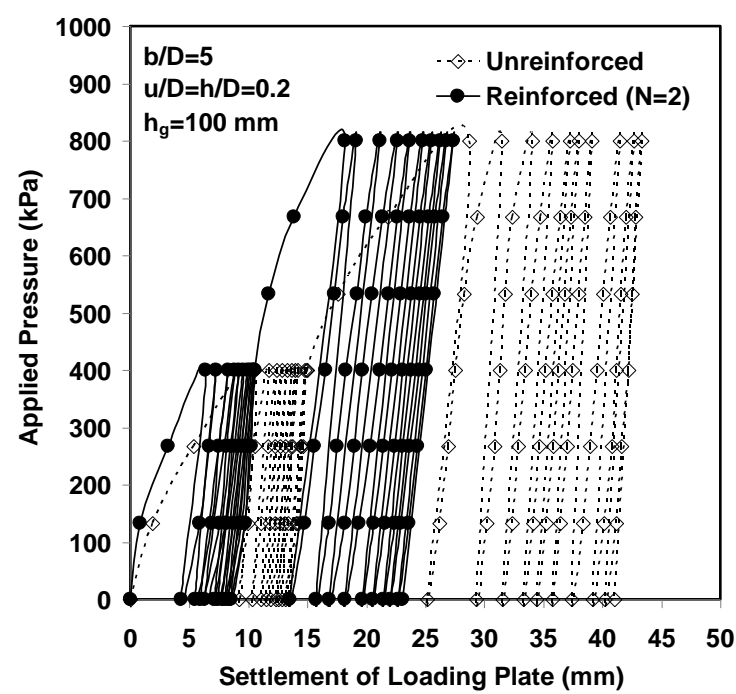

(b) $\mathrm{N}=2$

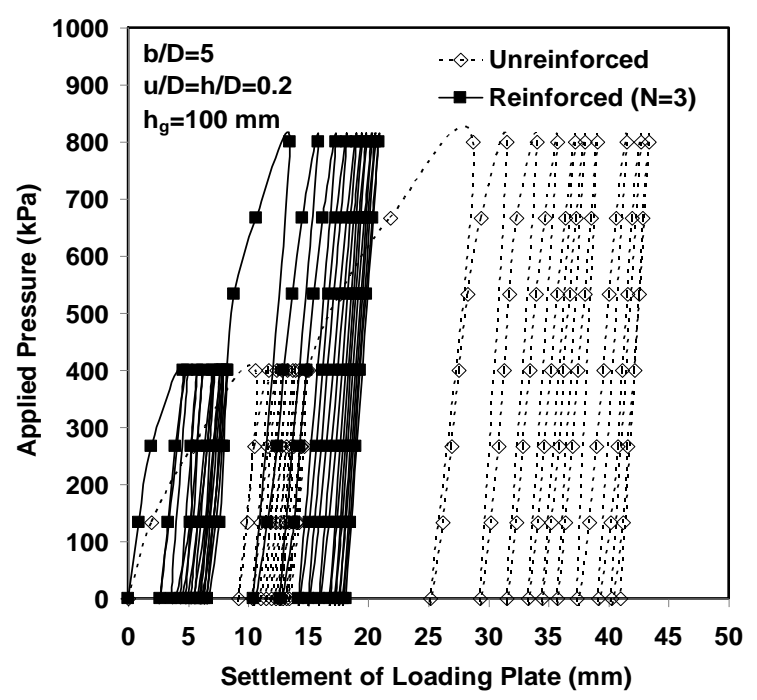

(c) $\mathrm{N}=3$

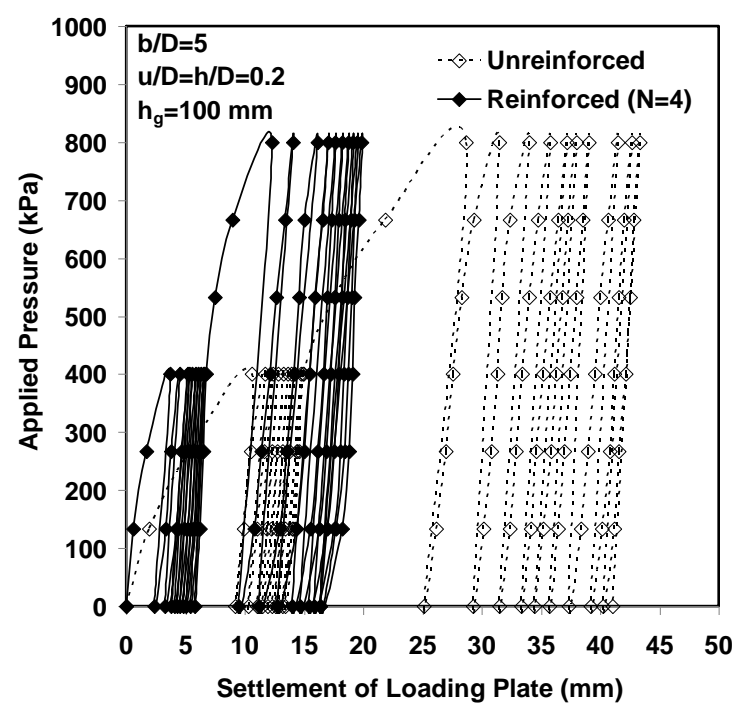

(d) $\mathrm{N}=4$

Figure 4. Comparison between unreinforced and improved geocellreinforced installations for different layers of geocell

This behaviour might be attributable to the energy absorbance properties of geocell reinforced system that is able to exhibit a higher capacity to absorb energy than soil alone under cyclic loading and tends to decrease the stress and shocks transferred into the depth of the backfill. The settlement reduction demonstrates that the geocell layers performed well in decreasing the soil settlement under cyclic loadings. It might be attributed to (1) The geocell reinforcement keeps the encapsulated soil from being displaced from directly beneath the applied load by confining the material by hoop action in the cell walls and behaves as a more rigid mattress, thereby increasing the shear strength of the composite system. The load redistribution that occurs within the confined zone involves a three-dimensional interaction between the infill materials and the cellular structure which spreads the applied load over an extended area, instead of directly at the point of contact, and provides a composite slab with high flexural stiffness and load support capabilities within the geocell reinforcement - consequently leading to an improvement in the overall settlement performance, and (2) Vertical stress applied to the infill induces a horizontal active pressure at the perimeter of the cell. The infill wall interface friction transfers load into the cell structure which, in turn, mobilizes 
resistance in surrounding cells and the geocell layers more rapidly attenuates the vertical applied stress in the soil perhaps because it is able to provide an anchorage effect on both sides of the loaded area known as "Vertical stress dispersion effect". Likewise, when the depth of the plate settlement increases the deformed shape of the geocell reinforcement, consequently the geocell reinforcement can provide a further tension force due to membrane effect.

\section{Summery and conclusion}

Based on the results obtained from the present study, the following conclusions can be made:

(1) Both the optimum depth of the topmost layer of geocell beneath the loading surface, and the optimum vertical spacing of geocell layers should be approximately 0.2 times loading plate diameter.

(2) Installation of the geocell layers in the foundation bed, increases the resilient behavior in addition to the reduction of the accumulated plastic and total settlement of the pavement foundation due, in part, to better load spreading of the composite system and to better energy absorbance properties of geocell.

(3) The rate at which further settlement then accumulates is much slower than under the first few cycles of loading. Its occurrence appears to depend on both the mass of reinforcement and the magnitude of the cyclic load applied to the loading plate. At the low level of cyclic load (400 $\mathrm{kPa}$ ), under fifteen load cycles applied to the loading plate, plastic shakedown (i.e. resilient response condition) occurs in all installations, irrespective of the reinforcement mass beneath the loading surface. At the high level of cyclic load $(800 \mathrm{kPa})$, for the test performed on the unreinforced pavement foundation, the surface settlement is relatively large and non-stabilizing at the end of cyclic loading. For the tests performed with a high reinforcement mass $(\mathrm{N}=3$, 4), plastic shakedown occurs. When using the low reinforcement mass $(\mathrm{N}=1,2)$, the rate at which settlement accumulates under cyclic loading is significantly reduced.

Since the tests results are obtained for only one type of soil, one type of geocell with one pocket size and one size of load diameter $(300 \mathrm{~mm})$, generalization may be needed, therefore, before these findings may be directly applied in practice. Thus, future tests with different materials (soil and geocell) and different sizes of load diameter would be very useful and could be used to validate the present findings. Although, the results provide considerable encouragement for the use of multiple layers of geocell reinforcement for addressing localized soft pavement foundation conditions, but economic assessments of multilayered geocell reinforcement, at commercial scale would need to be performed to assure users of the applicability of the findings in every situation.

\section{Acknowledgment}

The geocell used in this study was provided by DuPont de Nemours Company in the UK (the holder of the trademark on the GroundGrid ${ }^{\mathrm{TM}}$ and Typar ${ }^{\circledR}$ products). Also, Dr. T. Amirsoleymani, the managing director of Mandro Consulting Engineers and their technicians provided the loading system, pit, some of the instrumentations and great assistance during the tests. The research is also includes results created within the project SGS-2015-028 Semi-solid Processing and New Structures without Carbide Net and Institutional Support of the University of West Bohemia. The project SGS-2015-028 is subsidized from specific resources of the state budget for research and development

\section{References}

[1] American Association of State Highway and Transportation Officials (AASHTO) T 221-90. (2010), "Repetitive static plate load tests of soils and flexible pavement components for use in evaluation and design of airport and highway pavements".

[2] American Society for Testing and Materials. (2009), "Standard Test Method for Repetitive Static Plate Load Tests of Soils and Flexible Pavement Components, for Use in Evaluation and Design of Airport and Highway Pavements", ASTM, D 1195-09.

[3] American Society for Testing and Materials. (2011), "Standard Practice for Classification of Soils for Engineering Purposes (Unified Soil Classification System)". ASTM, D 2487-11.

[4] American Society for Testing and Materials. (2012), "Standard Test Methods for Laboratory Compaction Characteristics of Soil Using Modified Effort", ASTM, D 1557-12.

[5] Bathurst, R.J., Nernheim, A., Walters, D.L., Allen, T.M., Burgess, P. and Saunders, D.D. (2009), "Influence of reinforcement stiffness and compaction on the performance of four geosynthetic - reinforced soil walls", Geosynthetics International, 16 (1): 43-49.

[6] Boushehrian, A.H., Hataf, N. and Ghahramani, A. (2011), "Modeling of the cyclic behavior of shallow foundations resting on geomesh and grid-anchor reinforced sand", Geotextiles and Geomembranes 29 (3), 242-248.

[7] Chen, R.H., Huang, Y.W. and Huang, F.C. (2013), "Confinement effect of geocells on sand samples under triaxial compression", Geotextiles and Geomembranes 37 (2), 35-44

[8] Khalaj, O., Moghaddas Tafreshi, S.N., Mašek, B. and Dawson, A.R. (2015), "Improvement of pavement foundation response with multilayers of geocell reinforcement: Cyclic plate load test", Geomechanics and Engineering, 9 (3), 373-395.

[9] Koerner, R.M. (2012), "Designing with geosynthetics". 6th Edition Vol. 1. Xlibris Corporation, USA.

[10] Madhavi Latha, G. (2011), "Design of geocell reinforcement for supporting embankments on soft ground", Geomechanics and Engineering, an International Journal, 3 (2), 117-130.

[11] Madhavi Latha, G. and Rajagopal, K. (2007), "Parametric Finite Element Analyses of Geocell Supported Embankments", Canadian Geotechnical Journal, 44 (8), 917-927.

[12] Moghaddas Tafreshi, S.N. , Khalaj, O. and Dawson, A.R. (2013), "Pilot-scale load tests of a combined multilayered geocell and rubberreinforced foundation", Geosynthetics International. 20 (3), 143-161.

[13] Moghaddas Tafreshi, S.N. , Khalaj, O. and Dawson, A.R. (2014), "Repeated loading of soil containing granulated rubber and multiple geocell layers", Geotextiles and Geomembranes, 42 (1), 25-38.

[14] Pokharel, S.K., Han, J., Leshchinsky, D., Parsons, R. L. and Halahmi, I. (2010), "Investigation of factors influencing behavior of single geocell-reinforced bases under static loading", Geotextiles and Geomembranes 28 (6), 570-578.

[15] Sireesh, S., Sitharam, T.G. and Dash, S.K. (2009), "Bearing capacity of circular footing on geocell-sand mattress overlying clay bed with void", Geotextiles and Geomembranes 27 (2), 89-98.

[16] Tanyu, B. F., Aydilek, A. H., Lau, A. W., Edil, T. B. and Benson, C. H. (2013), "Laboratory Evaluation of Geocell-Reinforced Gravel Subbase Over Poor Subgrades", Geosynthetics International, 20 (2), $47-61$.

[17] Thakur, J.K., Han, J., Pokharel, S.K. and Parsons, R.L. (2012), "Performance of geocell-reinforced recycled asphalt pavement (RAP) bases over weak subgrade under cyclic plate loading", Geotextiles and Geomembranes 35 (December), 14-24.

[18] Yang, X., Han, J., Pokharel, S.K., Manandhar, C., Parsons, R.L. Leshchinsky, D. and Halahmi, I. (2012), "Accelerated pavement testing of unpaved roads with geocell-reinforced sand bases", Geotextiles and Geomembranes 32, (June), 95-103. 